\title{
A Comparative Study of the Cognitive Function of the Hearing-Impaired and Non-Hearing Impaired in Two Primary Schools in Lagos State, Nigeria
}

\section{Abstract}

Background: The study was carried out in two primary schools in Lagos State, Nigeria using 302 respondents aged 6-20 years. The study compared the cognitive function of pupils from Wesley School for the hearing-impaired with pupils from Onitolo Primary School, a main stream public school to see if similarities or differences existed in their cognitive function and to highlight the factors determining their performance on a standard non-verbal test.

Method: The instrument of data collection was the Raven's Standard Progressive Matrices, a standard, non-verbal intelligence test. Statistical association using Chi-Square was used to test for associations between categorical variables. Kruskal-Wallis was used to test for association in variables that were not normally distributed. Regression Coefficient was used to examine linear relationships between selected independent variables and the scores on the standardized test. As it was impossible to individually match human subjects in this study, the variables of class, sex, age and parents' occupations were adjusted for matching by multiple regression analysis. Multiple regression analysis was used to examine which variables were significant predictors of performance taking possible confounders into consideration.

Results: Respondents from Wesley School were much older than respondents from the public main-stream school, class for class. There was no statistically significant difference in their cognitive functions. The mean score difference between the two schools was 0.54 with respondents from Wesley School scoring higher $(P>0.05)$. Age, sex and class in primary school were determinants of score $(P<0.05)$. Males scored higher than females. Respondents of skilled parents had the highest scores. There was no relationship between the time the
Titilola T. Obilade MBBS, Ph.D.

Contact information:

Titilola T. Obilade MBBS, MPH, FMCPH, MWACP, MILD, Ph.D.

Senior Education Specialist Learning Sciences and Technology 144J Smyth Hall.

Virginia Polytechnic Institute and State University.

Blacksburg, Virginia, 24061- 0488.

”obilade@vt.edu 
child became hearing-impaired and their scores $(P>0.05)$. The mean score difference between children that became hearing-impaired by their first year of life and children that became hearing-impaired after the first year of life was $1.83(P>0.05)$. The children that became hearing-impaired before their first year of life scored higher $(P>0.05)$ than those that became hearing-impaired after their first year of life.

Conclusion: There was no statistically significant difference in the cognitive functions between the hearing-impaired and the non-hearing-impaired pupils. Age, sex and class were determinants of score $(P<0.05)$. In Nigeria, children that are hearing-impaired should be given equal opportunities especially in education.

\section{Keywords}

Hearing-impaired; cognitive function; standard non-verbal test; Lagos, Nigeria; Deaf; Wesley School; Onitolo School; performance; Intelligence Test; Raven's Intelligence Test

\section{Introduction}

The aim of the study was to assess and compare the cognitive function of two groups of students; the hearing-impaired and the non-hearing impaired using a standard non-verbal test.

\section{Objectives}

1. To determine the performance of the hearingimpaired group on a non-verbal standard test.

2. To determine the performance of the nonhearing-impaired group on a non-verbal standard test.

3. To determine the performance predictive factors in the two groups.

The World Summit for Children of which Nigeria is a signatory promised to give every child a better future [1]. The Universal Basic Education Program was introduced in Nigeria in 1999 further consolidating the vision of the 1990 World Summit [2]. The Universal Basic Education in Nigeria was introduced to give an equitable access to six years of primary school education and three years of a junior secondary school education [2].

In Nigeria, the challenges of the handicapped child are by no means insignificant. One of the difficulties faced with the hearing-impaired in Nigeria is that they fall behind in their academic achievements, leave school less qualified than their hearing peers and sometimes without any academic qualification of any kind. Further, their needs are sometimes not met because of parental superstitious beliefs about the hearing-impaired [3]. In some parts of Nigeria, when a child is born mute or deaf, it is believed that the child was born deaf to keep him/her from revealing the bad things that the family might have done [3]. Less educational resources are given to the handicapped child by the Nigerian Government $[4,5]$.

The rate of unemployment in Nigeria is exceptionally high [6] and while the non-hearing impaired are not able to get jobs, it is even more difficult for the hearing-impaired to secure jobs because they 
leave school less qualified. They hardly go beyond the primary school level because it is believed that the resources spent on them can be directed to children that are not hearing-impaired $[4,5]$ and that they have a lesser cognitive capacity [7]. In Nigeria, few educational facilities support the hearing-impaired beyond the primary school curriculum and even fewer beyond the secondary school curriculum [5].

Cognitive functions include the mental processes of thinking, perceiving and understanding. This study hopes to examine any similarities or differences that may exist in the cognitive functions of the hearing-impaired and the non-hearing-impaired in Lagos, Nigeria.

\section{Literature Review}

\section{Verbal and Non Verbal Tests on the Hearing-Impaired}

There is a disagreement even amongst experts about the thinking processes of people with hearing impairments [8]. Spoken language and the written word were thought to be linked to intelligence $[7,8]$. For some time, cognitive studies conducted on the hearing-impaired suggested that they were intellectually inferior to the non-hearing impaired person $[7,8]$. These studies used verbal tests that put the hearing-impaired at a disadvantage because of the spoken language. However, studies have shown that the use of sign language by the hearing-impaired did not diminish their level of intelligence [7]. On the contrary, studies have also revealed that the hearing-impaired who use the natural signed language have an advantage in visual spatial abilities [7].

A study conducted in India showed that when deaf children that had never been taught sign language were examined on visual spatial abilities, their performance was not different from non-hearing-impaired children which led the researchers to conclude that learning the sign language played a role in the observed enhancement of visual spatial abilities in the hearing-impaired [9]. Most hearingimpaired children have hearing parents and so communicating in the first few years of life with parents that do not understand the signed language may cause some delays in cognitive development [7] and may become even more apparent when the child is not taught the sign language in his/her first few years of development. Sometimes, children are not diagnosed as hearing-impaired until around the age of 5 years [10].

At a study conducted in Ibadan, Nigeria, the mean age of diagnosis of sensorineural hearing loss was 5.8 years [10]. The study was conducted at the otorhinolaryngology clinic of the University College Hospital, Ibadan, Nigeria. It revealed that out of the 713 patients seen between 2000 and 2005, 103(14\%) were diagnosed with sensorineural hearing loss [10]. The four main causes of sensorineural hearing loss in the study were congenital, viral infections, ototoxity and meningitis. The other causes were chronic suppurative otitis media, idiopathic, hemoglobinopathies and trauma [10]. This study hopes to highlight the cognitive functioning level of the hearing-impaired persons using a nonverbal test; Raven's Standard Progressive Matrices [11].

The study of the cognitive abilities of hearingimpaired children is important for both practical and theoretical reasons. Practically, it helps to determine appropriate teaching strategies and theoretically, it helps to examine the role of absence or presence of verbal language in cognitive processes particularly for the Nigerian environment. Most studies have shown that hearing-impaired children are similar to the non-hearing-impaired in virtually all aspects of cognitive function [8]. Many studies have also emphasized pronounced differences in their academic achievement $[7,8]$. However, some intelligence tests have biases that give advantage to respondents from a particular environment and to children of certain ethnicities $[12,13]$. Apart from intelligen- 
ce tests for the hearing-impaired, other intelligence tests that have a verbal component have also been found to be biased. Intelligence tests to determine gifted children were found to be biased because the verbal component was found to be in favor of White children [13]. When children from minority populations and White populations were tested on a standard non-verbal test for gifted children, the two groups performed at the same level [13].

\section{Environment and Intelligence}

A lot of research on environment and intelligence level has been conducted in countries that rank high on the United Nations Development Program (UNDP) Human Development Index and the results were used to interpret level of intelligence on people from countries that rank low on the Human Development Index [14]. Environmental factors impact cognitive attainment. A cross sectional study in Baghdad City, Iraq using the Colored Raven's Matrices showed that children that performed poorly on the Colored Raven's Matrices lived in stressful environments [15]. Therefore, it would be more meaningful if results of intelligence tests conducted in environments similar to the participants are used in their interpretation $[14,15]$.

Studies on cognitive functioning have been conducted in different parts of the world within different environments but baseline data do not exist for students attending Wesley School for the hearingimpaired in Lagos, Nigeria or for hearing-impaired children in Nigeria. There are a lot of challenging situations in Nigeria and such challenges become even more apparent for the hearing-impaired and for those with other disabilities.

\section{The terms impairment, disability and handicap}

The terms impairment, disability, and handicap are often used interchangeably. The World Health Organization (WHO) defined the three terms in the International Classification of Impairments, Disabilities and Handicaps (ICIDH) [16]. Impairments give rise to disabilities which can eventually become a handicap. Impairments are disturbances at the level of a bodily organ, system or function, whether physical or mental, while a disability is the objectification of the impairment reflecting functional disturbances at the level of the individual. Handicaps are the disadvantages experienced by the individual with the impairment and disability in his/her interaction to adapt to the environment.

As an example, while sensorineural hearing loss from an infection is an impairment, it results in the disability of being unable to hear or having difficulty in hearing. The term handicap refers to the social, cultural, environmental or economic consequences of the disability and impairment which put the concerned person at a disadvantage. A mobility handicap would describe a person using a wheel chair because s/he cannot make use of his/her limbs after infection with poliomyelitis. The disability would be the inability to use the limbs and the impairment would be at the level of the nervous system.

A newer classification similar to ICIDH is the International Classification of Functioning, Disability and Health (ICF) based on the earlier ICIDH classification. The ICF uses newer terms like body functions and structure, disability, activity and participation $[17,18]$. There are similarities in their description of impairment and disability. Body functions and structure in ICF are used in terms similar to impairment in ICIDH while individual level activities in the ICF describe terms similar to disability in the ICIDH. Society level participation as described in ICF describes handicap from disabilities and impairments. It places disability in the context of the environment and not necessarily as a physical disability. It points to the negative impact the disability has on the individual in the context of his/her environment. The hearing-impaired pupils in the study were examined in the context of their environment with nonhearing-impaired pupils attending school from the same local government area. The two schools in the study were about three miles apart. 
The aim of this study was to examine the cognitive function of the hearing-impaired students from Wesley Primary School and compare it with pupils from Onitolo Primary School that are not hearingimpaired using a standard non-verbal intelligence test. This study would also be a resource for baseline data on hearing-impaired children from Lagos, Nigeria. This research paper would not describe the non-hearing impaired pupils as the normal group because doing so would imply that the hearingimpaired are not normal or imply that they are less than normal which would be a bias and would not be in alignment with the classification by the World Health Organization (WHO).

\section{Methodology}

Wesley School: Wesley School for deaf children was named after the founding father of the Methodist Church, John Wesley. Education for the hearingimpaired started in 1956 but the present site was commissioned in 1962. A group of friends started the school. This group of friends played with the children at the King's palace in Adeniji Adele, Lagos State. The Methodist church was later approached for teachers and was originally sponsored by the Methodist Mission. The school started with 30 pupils at the present site but there were facilities for 80 children. Two sets of Wesley schools exist within the same premises and they are both called Wesley School. Separately, they are known as Wesley School 1 and Wesley School 2. Together, they are known as Wesley School. The entry age into the school is 6 years old. There is no educational facility for hearing-impaired children below the age of six years in Lagos State, Nigeria. Wesley School for the deaf as it was formally called was formally under the Federal Government of Nigeria but it is now managed by the State Government.

The present site was built by the Federal Government and commissioned in 1962. Initially, it had boarding facilities which were later canceled by the second civilian governor of Lagos State. Some of the students have gained admission into Lagos State Grammar School which has educational facilities for the hearing-impaired. Pupils that cannot cope in the secondary school attend trade centers where they learn carpentry, electrical installation and other trades. A graduate of Wesley School has gone on to the University of Ilorin, Nigeria and studied History. The University of Ilorin, Nigeria has a unit that can teach the hearing-impaired. Many of the graduates have returned to the school to teach. At the time of data collection, Wesley School 1 had a population of 183 pupils in classes 1-6 and 18 teachers. It is a non-fee paying school apart from the Parents Teachers Association fee which is an equivalent of ten dollars. They are also given one free meal a day because it is a special school. The milk system took effect since January 2003. The pupils in primary one are given milk once a week courtesy of the Lagos State Government.

The entrance into secondary schools is by a National Common Entrance, continuous assessments of primaries, 4, 5 and 6 or the Lagos State Common Entrance. It is only pupils that are deemed capable of writing the entrance exam that sit for the exam. In 2003, six students sat for the entrance exam. The students that attend the school communicate through the sign language.

Onitolo Primary School: The School now known as Onitolo primary School was originally named Government Demonstration School. The school was founded by the first civilian government on the 13th of January, 1958 and officially opened in May, 1958. After the creation of Lagos State in 1967, the administration and financing of both the teachers' college and school was transferred to the State Education Ministry. The population of the school rose to over 2000 in 1976. The milk system was introduced to only pupils in nursery and those in primary one in 2003. They are given a cup of milk twice a week. The milk is supplied free by the Lagos State Government. The pupils do not pay fees apart from 
the Parents Teachers Association fee which is an equivalent of ten dollars. At the time of the data collection, the school had thirteen teachers, 245 pupils including 120 boys and 125 girls.

\section{Type of Study}

This study was a quantitative, comparative, analytical study between two primary schools in Lagos, Nigeria. A total population of 141 pupils from Wesley School that fitted into the inclusion criteria was examined out of a total population of 183 students. In Onitolo School, 161 students that fitted into the inclusion criteria were examined out of a total population of 245 students. Some students in Onitolo School were also absent during the study because they were sitting for exams.

\section{Inclusion Criteria for pupils from Wesley School (hearing-impaired)}

1. The pupil must be hearing-impaired and between 6 to 21 years old as at the last birthday.

Exclusion criteria for pupils from Wesley School (hearing-impaired)

1. The pupil is not in the age bracket of 6 to 21 years old as at the last birthday.

2. The pupil has other disabilities affecting any of the other senses..

Inclusion Criteria for pupils from Onitolo School (non-hearing impaired/ main stream school)

1. The pupil is between 6-21 years old as at the last birthday.

Exclusion Criteria for pupils from Onitolo School (non-hearing impaired)

1. The pupil is not in the age bracket of 6 to 21 years old as at the last birthday.

2. The pupil has disabilities affecting any of the senses.

\section{Ethical Clearance}

Permission for the study was granted by the Ethical Committee of the Lagos University Teaching Hospital. Proper protocol on human subjects was adhered to in both schools. The study was non-invasive. Permission was also obtained from the principals, head teachers and parents. In each school, data collection took an entire day.

\section{Ethical Consideration}

The data collection disrupted the schedules of the two schools for about 45 minutes to 3 hours depending on how long it took the respondents to finish the non-verbal standard test. On the nonverbal standard test, respondents are not given a time limit and so the time range to complete the tests ranged from 45 minutes to 3 hours. Data was collected from Wesley School in the morning and data was collected from Onitolo Primary School in the morning or afternoon depending on the class schedules. Some respondents missed up to two classes on the day the data was collected.

\section{Consent Statement}

Parents signed a consent form before their children were allowed to participate. Parents and guardians of pupils older than eighteen years old also signed a consent form. Guardians signed the consent form for pupils that did not live with their parents.

\section{Data Collection}

A comprehensive list of primary schools in Surulere Local Government, Lagos State was obtained from the Surulere Local Government, Lagos, State and Onitolo Primary School was selected by simple random sampling from a list of 61 primary schools. Wesley School is the only government school for the hearing-impaired in Lagos State and so it was chosen by purposive sampling. Wesley School and Onitolo School are both in the same local government so students attending any of the two schools share similar physical environments.

Any pupil attending Wesley School must have hearing impairment that necessitates enrolment in a school for the hearing-impaired. This study was not conducted to assess their level of hearing-impairment against their cognitive functioning on a standard non-verbal test. It follows that any pupil attending the school and fitted into the inclusion 
criteria regardless of the level of hearing-impairment was included in the study.

As it was impossible to individually match human subjects in this study, the variables of class, sex, age and parents' occupations were adjusted for matching by multiple regression analysis. Multiple regression analysis took possible confounders into consideration. The open-ended questionnaire was sent home to be filled by parents or guardians. The cognitive test was conducted using a non-verbal standard test.

\section{Instruments of data collection \\ Questionnaire on the socio-demographic data}

The questionnaire on the socio demographic data consisted of ten open-ended questions. These questionnaires were given to each pupil to take home and return the following day. The tenth question was directed to the respondents from Wesley School. The tenth question was asked to determine the age at which the child became hearing-impaired. Some of the questionnaires were not returned. Therefore, some of the information was obtained from the schools' records. Information that could not be obtained was considered a non-response. The data on non-response was not included in the statistical tests.

In the questionnaire, seven categories of groups were identified under occupations. The British Registrar General's classification of occupations was used to categorize the parents' occupations [19]. These were (doctors, scientists), (small business owners, teachers), (clergy, pastors), (factory workers, agricultural workers), (domestic servants, casual employees), unemployed and the deceased. Some of those who worked as skilled workers were selfemployed and had completed their education up to the tertiary level.

\section{The classification of parents' occupations}

For a long time, occupations have been used to classify respondents and to infer their social class
[20]. Occupation classifications have also been used to study job risks and to infer exposure to harmful agents through the job [20]. A review of 129 articles published in the British Medical Journal, American Journal of Epidemiology and International Journal of Epidemiology between 1995 and 2000 showed that occupation classifications were used in 38\% of epidemiological studies as an indicator of social class, 27\% were articles that examined occupations, $24 \%$ were articles on exposure to a disease and the remaining $11 \%$ were studies that examined occupation as a confounding factor [20].

The British Registrar General's Scale is the most widely used classification for occupations [21]. It was started in 1801 but the popular British Registrar General's Scale used in social class and occupations was first introduced in 1921[19]. It was used to classify the head of household's occupation along five major categories [19, 21]. The five major categories were I professional, II intermediate, III skilled, IV partly skilled, and V unskilled [19]. In 1970, the classification was revised by dividing class III; manual into manual and non-manual [19, 21]. The categories in the British Registrar General's Scale used in this study were; I professional; II managerial and technical; III N skilled non-manual; III M skilled manual; IV partly skilled; $V$ unskilled and deceased). These scales are ranked hierarchically according to the level of skill.

Some variables may affect the social class inferred from occupations [19-21]. These variables include the number of siblings in the home, the morbidity and use of services, developmental outcomes of the children, age of the mother and the educational qualification of the parents [19]. In the present study, multiple regression analysis was conducted taking possible confounders into consideration.

\section{The Non-Verbal Standard Test}

The non-verbal standard test used was the Standard Raven's Progressive Matrices [11]. It was in black and white. It consisted of 60 matrices that were divided 
Table 1. The 1980 and 1921 British Registrar General's Classification.

\begin{tabular}{|c|c|c|c|}
\hline Codes & & Occupations & \\
\hline I & & Professional & \\
\hline II & & Intermediate & \\
\hline III & & Skilled & \\
\hline IV & & Partly Skilled & \\
\hline V & & Unskilled & \\
\hline & \multicolumn{2}{|l|}{ Codes } & Occupations \\
\hline & \multicolumn{2}{|l|}{ । } & Professional \\
\hline & \multicolumn{2}{|l|}{$\|$} & Intermediate \\
\hline & \multicolumn{2}{|l|}{ III M } & Manual \\
\hline & \multicolumn{2}{|l|}{ III NM } & Non Manual \\
\hline & \multicolumn{2}{|l|}{ IV } & Partly Skilled \\
\hline & \multicolumn{2}{|c|}{ V } & Unskilled \\
\hline & \multicolumn{2}{|c|}{$\begin{array}{l}\text { Not Classified including } \\
\text { fatherless families }\end{array}$} & \\
\hline
\end{tabular}

Table 2. Classifications for occupations used in this study (according to the British Registrar General's Classification).

\begin{tabular}{l|l|}
\hline Occupation & Social Class \\
\hline $\begin{array}{l}\text { Doctors, Scientists } \\
\text { Small business owners, teachers }\end{array}$ & II \\
\hline $\begin{array}{l}\text { Clergy, Pastors } \\
\begin{array}{l}\text { Factory workers, agricultural } \\
\text { workers }\end{array}\end{array}$ \\
$\begin{array}{l}\text { Domestic servants, casual } \\
\text { employees }\end{array}$ & III \\
\hline $\begin{array}{l}\text { Unemployed } \\
\text { Deceased }\end{array}$ & V \\
\hline
\end{tabular}

into five sets. Each set consisted of 12 items each. The test involved completing the missing part in the matrices. As the pupil progressed in the test, the matrices became increasingly difficult. The correct alternative to complete the matrix must be selected from six or eight options. There was no time limit for the test.

The seats were spaced to avoid the pupils helping each other out. The students were allowed to finish the entire test. A total of 141 pupils were tested in Wesley School and a total of 161 pupils were tested in Onitolo Primary School. Wesley School teachers identified the pupils that met the inclusion criteria. The teachers in Wesley School instructed their pupils through the sign language. In Onitolo Primary School, the Principal Investigator instructed the pupils from primary one to primary six. The teachers in Onitolo identified the pupils that fitted into the inclusion criteria. In Wesley School, it took a range of 45 minutes to 3 hours to answer the standard non-verbal test and in Onitolo Primary School, it took a range of 45 minutes to 2 hours to answer the standard non-verbal test.

\section{The Tests was scored using the key below}

55-60 Intellectually Superior 45-54 Above Average Intellectual Capacity

11-29 Below Average Intellectual Capacity

\section{Data Analysis and Interpretation}

Data was collected and analyzed for statistical association using EPI info version 6 [22] statistical software. Raw data was coded and input into a computer by the Principal Investigator. Errors in the data entry were then cleared to remove entry errors. Tests of association analysis and interpretation were done and reviewed by a biostatistician.

Kruskal-Wallis was used to test for association that was not normally distributed. Variables that were not found to be statistically significant to performance in the bivariate analysis of all the independent variables were also included in the multiple regression analysis. Sex was included in the multi-
30-44 Average Intellectual Capacity 
ple regression analysis. Bivariate analysis was not done on sex because it is not a continuous variable. However, it was included in the multiple regression analysis because there was a statistically significant difference in the mean scores between the sexes.

Statistical association using Chi-square was used to test for associations between categorical variables. Regression Coefficient was used to examine linear relationships between selected independent variables and multiple regression analysis was used to examine which variables were significant predictors of performance taking possible confounders into consideration. Standard deviation was calculated for the mean scores to determine their spread. The level of significance for all the statistical tests was a $P$ value of 0.05 .

\section{Results}

The main results are included in the following tables:

Table 3: Socio Demographic Distribution of Respondents.

\begin{tabular}{|c|c|c|c|c|c|}
\hline \multicolumn{6}{|c|}{ Number of Respondents in both School } \\
\hline School & \multicolumn{4}{|c|}{ Frequency } & Percentage \\
\hline Wesley & \multicolumn{4}{|l|}{141} & 46.7 \\
\hline Onitolo & \multicolumn{4}{|l|}{161} & 53.3 \\
\hline Total & \multicolumn{3}{|l|}{302} & & 100 \\
\hline \multicolumn{6}{|c|}{ Sex of Respondents in both Schools } \\
\hline Sex & & Wesley $n(\%)$ & Onitolo n (\%) & & $\begin{array}{c}\text { Non Response }=5 \\
\qquad P<0.05\end{array}$ \\
\hline Female & & $58(41.1)$ & $81(50.3)$ & 139 & \\
\hline Male & & $78(55.3)$ & $80(49.7)$ & 158 & \\
\hline Total & & 136 & 161 & 297 & \\
\hline \multicolumn{6}{|c|}{ Religion of Respondents in both Schools } \\
\hline Religion & & Wesley $n(\%)$ & Onitolo n (\%) & Total & $\begin{array}{c}\text { Non Response }=22 \\
P>0.05\end{array}$ \\
\hline Christian & & $92(65.2)$ & $86(53.4)$ & 178 & \\
\hline Muslim & & $27(19.1)$ & $75(46.6)$ & 102 & \\
\hline Total & & 119 & 161 & 280 & \\
\hline \multicolumn{6}{|c|}{ Ethnic Distribution of Respondents in both Schools } \\
\hline Ethnicity & & Wesley $n(\%)$ & Onitolo n (\%) & Total & $\begin{array}{l}\text { Non Response }=0 \\
\quad P>0.05\end{array}$ \\
\hline Hausa & & $2(1.4)$ & $1(0.6)$ & 3 & \\
\hline Igbo & & $31(22.0)$ & $17(10.6)$ & 48 & \\
\hline Yorubas & & $73(51.8)$ & $121(75.2)$ & 194 & \\
\hline Others & & $35(24.8)$ & $22(13.7)$ & 57 & \\
\hline Total & & 141 & 161 & 302 & \\
\hline \multicolumn{6}{|c|}{ Age Distribution of Respondents } \\
\hline Age (in Years) & & Wesley n (\%) & Onitolo n (\%) & Total & $\begin{array}{l}\text { Non Response }=4 \\
\qquad P>0.05\end{array}$ \\
\hline $6-10$ & & $41(28.5)$ & $103(71.5)$ & 144 & \\
\hline $11-15$ & & $76(53.9)$ & $55(34.2)$ & 131 & \\
\hline $16-20$ & & $22(15.6)$ & $1(0.6)$ & 23 & \\
\hline Total & & 139 & 159 & 298 & \\
\hline
\end{tabular}




\section{INTERNATIONAL ARCHIVES OF MEDICINE

\begin{tabular}{|l|c|c|c|c|}
\hline Occupations & Wesley $n(\%)$ & Onitolo $n(\%)$ & Total & $\begin{array}{c}\text { Non Response }=57, \\
\text { P }\end{array}$ 0.05 \\
\hline Doctors, Scientists & $11(7.8)$ & $25(15.5)$ & 36 \\
\hline Small business owners, teachers & $23(16.3)$ & $66(41.0)$ & 89 \\
\hline Clergy, Pastors & $21(14.9)$ & $25(15.5)$ & 46 \\
\hline Factory workers, agricultural workers & $29(20.6)$ & $19(11.8)$ & 48 \\
\hline Domestic servants, casual employees & $5(3.5)$ & $6(3.7)$ & 11 \\
\hline Unemployed & $2(1.4)$ & $3(1.9)$ & 5 \\
\hline Deceased & $7(5.0)$ & $3(1.9)$ & 10 \\
\hline Total & 98 & 147 & 245 \\
\hline
\end{tabular}

Distribution of Respondents in both Schools according to Mothers' Occupation

\begin{tabular}{|l|c|c|c|c|}
\hline Occupations & Wesley $n(\%)$ & Onitolo $n(\%)$ & Total & $\begin{array}{c}\text { Non Response }=47, \\
\text { P }>0.05\end{array}$ \\
\hline Doctors, Scientists & $7(5.0)$ & $11(6.8)$ & 18 \\
\hline Small business owners, teachers & $72(51.1)$ & $109(68.7)$ & 181 \\
\hline Clergy, Pastors & $5(3.5)$ & $5(3.1)$ & 10 \\
\hline Factory workers, agricultural workers & $6(4.3)$ & $15(9.3)$ & 21 \\
\hline Domestic servants, casual employees & $4(2.8)$ & $3(1.9)$ & 7 \\
\hline Unemployed & $10(7.1)$ & $4(2.5)$ & 14 \\
\hline Deceased & $1(0.7)$ & $3(1.9)$ & 4 \\
\hline Total & 105 & 150 & 255 \\
\hline
\end{tabular}

\begin{tabular}{|l|c|c|c|c|}
\hline \multicolumn{2}{|c|}{ Distribution of Respondents by Class in Primary School } \\
\hline Class in Primary School & Wesley $n(\%)$ & Onitolo $n(\%)$ & Total & $\begin{array}{c}\text { Non Response }=2 \text {, } \\
\mathrm{P}<0.05\end{array}$ \\
\hline 1 & $30(21.3)$ & $15(9.3)$ & 45 \\
\hline 2 & $20(14.2)$ & $15(9.3)$ & 35 \\
\hline 3 & $23(16.3)$ & $40(25.0)$ & 63 \\
\hline 4 & $17(12.1)$ & $31(19.4)$ & 48 \\
\hline 5 & $22(15.6)$ & $26(16.2)$ & 48 \\
\hline 6 & $28(19.9)$ & $33(20.6)$ & 61 \\
\hline
\end{tabular}

Table 4. Means of scores for both schools.

\begin{tabular}{|l|c|c|c|c|} 
School & $\begin{array}{c}\text { Number of } \\
\text { Students }\end{array}$ & Mean & $\begin{array}{c}\text { Standard } \\
\text { Deviation }\end{array}$ & $\begin{array}{c}\text { Kruskall Wallis P } \\
\text { Value }>0.05\end{array}$ \\
\hline Wesley & 141 & 16.60 & 4.87 & \\
\hline Onitolo & 161 & 16.07 & 4.59 & \\
\hline
\end{tabular}

Table 5. Age at which children in Wesley School became hearing-impaired.

\begin{tabular}{|l|c|c|c|}
\hline $\begin{array}{l}\text { Age } \\
\text { (in years) }\end{array}$ & Frequency & Percentage & Non Response = 39 \\
\hline 1 & 76 & 74.5 & \\
\hline 2 & 11 & 10.8 & \\
\hline 3 & 6 & 5.9 & \\
\hline 4 & 5 & 4.9 & \\
\hline 5 & 2 & 2.0 & \\
\hline Above 5 & 2 & 1.9 & \\
\hline Total & 102 & 100 & \\
\hline
\end{tabular}


Figure 1: Comparison of the Standard Non Verbal Test Scores between Males and Females in Both Schools.

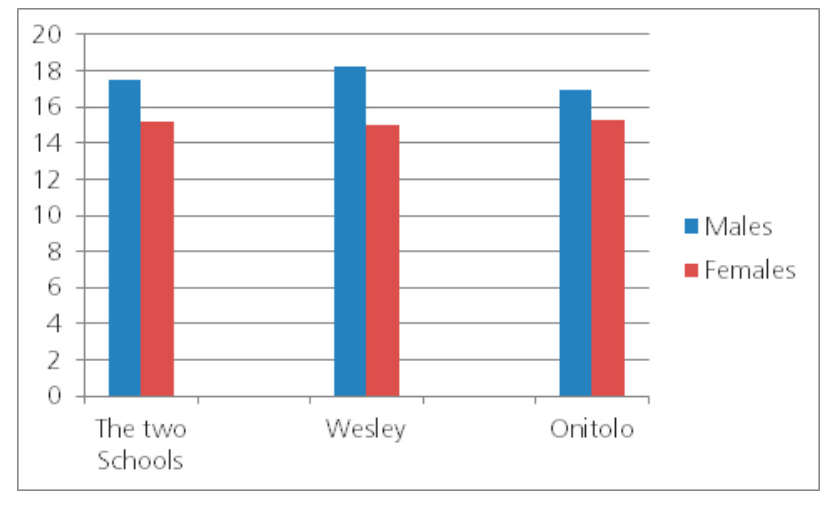

Figure 2: Percentage Distribution of Pupils in Wesley School by their Scores

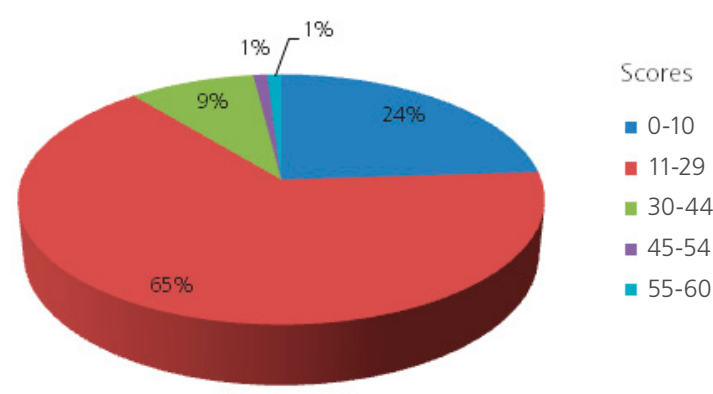

Figure 3: Percentage Distribution of Pupils in Onitolo School by their Scores

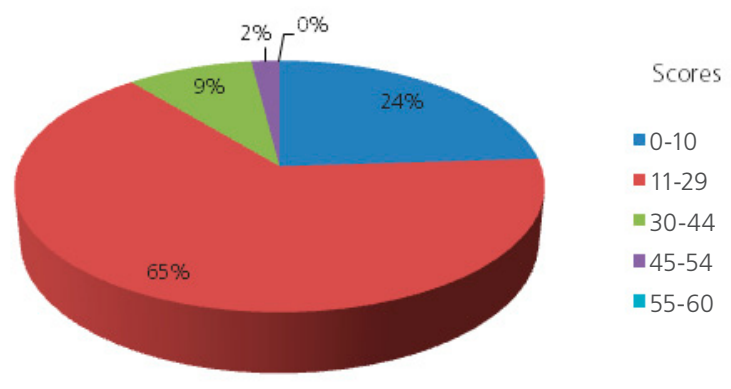

Figure 4: Mean scores by class among pupils in Wesley School

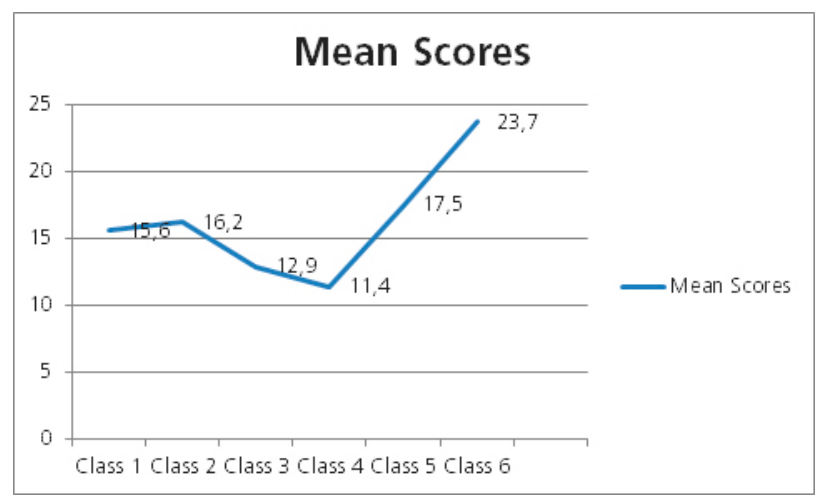

Figure 5: Mean scores by class among pupils in Onitolo School

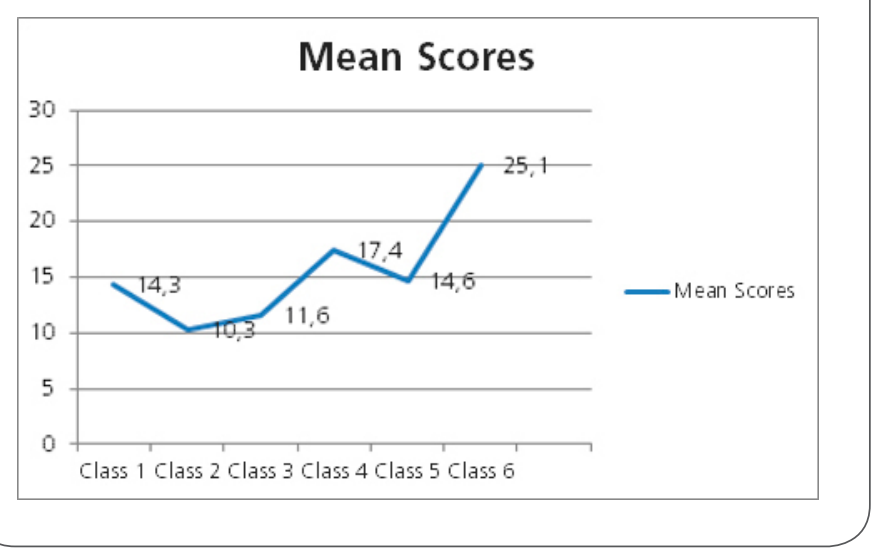

\section{Socio-demographic}

Out of a total of 302 respondents, 141 were from Wesley and 161 were from Onitolo. Altogether, there were more males 158 (53.2\%) than females. However, Wesley School had more males 78 (55.3\%) and Onitolo School had more females $81(50.3 \%)$. About two-thirds of the respondents $178(63.6 \%)$ were Christians. A greater proportion 194 (64.2\%) were Yorubas.

In Wesley School, majority of the respondents 76 (53.9\%) were between 11-15 years and in Onitolo, most were younger 103 (71.5\%) and aged between 6-10 years. In Onitolo Primary school, majority of the fathers and mothers 175 (56.6\%) were owners of small businesses or teachers. In Wesley School, most of the fathers 29 (20.6\%) were factory workers 
or agricultural laborers while most of the mothers $72(51.1 \%)$ were owners of small businesses or teachers.

In Wesley School, most respondents 58 (41.4\%) were from primaries one and six and in Onitolo School, most were from primaries three and six 73 (42.9\%). Majority of the respondents in Wesley School 76 (74.5\%) became hearing-impaired by their first birthday. The Vice Principal of Wesley School informed the Principal Investigator that many of the parents reported that their child had had jaundice at birth, or fever or measles before the child was no- ticed to be hearing-impaired. One 11 year old child in Wesley School became hearing-impaired at the age of nine years from a sickness the parents could not determine. This 11 year old child scored 35 and the mean score for his class was 16.20 .

\section{Scores}

On the Standard non-verbal test, males from Wesley School scored higher than the males from Onitolo School $(P>0.05)$. The Onitolo females scored higher than the Wesley females. The males in both schools scored higher than the females.

Table 6. Relationship between the age the child became hearingimpaired and the score on the Standard non-verbal test.

\begin{tabular}{|l|c|c|}
\hline Variable & Regression Coefficient & P Value \\
\hline Age child became hearing-impaired & -0.06 & $P>0.05$ \\
\hline
\end{tabular}

Table 7. Means of scores in the two schools by class in primary School.

\begin{tabular}{|l|c|c|c|c|c|}
\hline & \multicolumn{3}{c|}{ Wesley } & \multicolumn{2}{c|}{ Onitolo } \\
\hline $\begin{array}{l}\text { Class in Primary } \\
\text { School }\end{array}$ & Means of Scores & $\begin{array}{c}\text { Standard } \\
\text { Deviation }\end{array}$ & Means of Scores & $\begin{array}{c}\text { Standard } \\
\text { Deviation }\end{array}$ & $\begin{array}{c}\text { Kruskal Wallis P } \\
\text { Value }\end{array}$ \\
\hline 1 & 15.60 & 3.50 & 14.27 & 0.79 & $>0.05$ \\
\hline 2 & 16.20 & 3.81 & 10.27 & 4.60 & $>0.05$ \\
\hline 3 & 12.71 & 4.45 & 11.55 & 2.62 & $>0.05$ \\
\hline 4 & 11.41 & 3.34 & 17.36 & 3.27 & $* 0.05$ \\
\hline 5 & 17.46 & 3.77 & 14.62 & 3.49 & $>0.05$ \\
\hline 6 & 22.93 & 5.98 & 25.06 & 5.42 & $>0.05$ \\
\hline
\end{tabular}

Table 8. Comparison of means of scores by the age child became hearing-impaired.

\begin{tabular}{|l|c|c|c|c|}
\hline Age child became hearing-impaired & Frequency & Mean of Scores & Standard Deviation & $\begin{array}{c}\text { Kruskall Wallis P Value for } \\
\text { score means }>0.05\end{array}$ \\
\hline By First year of Life & 76 & 17.41 & 5.56 & \\
\hline After first year of Life & 26 & 15.58 & 3.56 & \\
\hline
\end{tabular}


Table 9. Bivariate analysis of selected variables.

Bivariate Analysis of selected variables among respondents in Wesley School

\begin{tabular}{|c|c|}
\hline Variables & P Value \\
\hline Age & $P<0.05$ \\
\hline Father's Occupation & $P>0.05$ \\
\hline Mother's Occupation & $P>0.05$ \\
\hline Class in Primary School & $P<0.05$ \\
\hline \multicolumn{2}{|c|}{$\begin{array}{l}\text { Bivariate Analysis of selected variables among respondents in } \\
\text { Onitolo School }\end{array}$} \\
\hline Variables & P Value \\
\hline Age & $<0.05$ \\
\hline Father's Occupation & $>0.05$ \\
\hline Mother's Occupation & $>0.05$ \\
\hline Class in Primary School & $<0.05$ \\
\hline \multicolumn{2}{|c|}{ Bivariate Analysis of selected variables in both SchoolsSchool } \\
\hline Variables & P Value \\
\hline Age & $<0.05$ \\
\hline Father's Occupation & $>0.05$ \\
\hline Mother's Occupation & $>0.05$ \\
\hline Class in Primary School & $<0.05$ \\
\hline
\end{tabular}

Table 10. Multiple Regression Analysis showing the Relationship between Performance and Selected Independent Variables among Respondents.

Multiple Regression Analysis showing the relationship between performance and selected independent variables among respondents in Wesley School

\begin{tabular}{l|r}
\hline Variables & P Value \\
\hline Age & $<0.05$ \\
Sex & $<0.05$ \\
\hline Father's Occupation & $>0.05$ \\
Mother's Occupation & $>0.05$ \\
Class in Primary School & $>0.05$
\end{tabular}

Multiple Regression Analysis showing the relationship between performance and selected independent variables among respondents in Onitolo School

\begin{tabular}{l|l}
\hline Variables & P Value \\
\hline Age & $>0.05$ \\
Sex & $>0.05$ \\
\hline Father's Occupation & $>0.05$ \\
Mother's Occupation & $>0.05$ \\
Class in Primary School & $<0.05$
\end{tabular}

Multiple Regression Analysis showing the relationship between performance and selected independent variables among respondents in both schools

\begin{tabular}{l|r}
\hline Variables & P Value \\
\hline Age & $>0.05$ \\
Sex & $>0.05$ \\
\hline Father's Occupation & $>0.05$ \\
Mother's Occupation & $>0.05$ \\
Class in Primary School & $<0.05$
\end{tabular}


Table 11: Distribution of Means of Scores by Occupation in both Schools.

\begin{tabular}{|c|c|c|c|}
\hline \multicolumn{4}{|c|}{ Distribution of means of scores by fathers' occupation in both schools } \\
\hline Occupation & Means of Scores in Wesley & Means of Scores in Onitolo & Kruskal Wallis P Value \\
\hline Doctors, Scientists & 18.29 & 16.62 & $>0.05$ \\
\hline Small business owners, teachers & 16.44 & 16.28 & $>0.05$ \\
\hline Clergy, Pastors & 12.22 & 14.00 & $>0.05$ \\
\hline Factory workers, agricultural workers & 14.69 & 13.95 & $>0.05$ \\
\hline Domestic servants, casual employees & 13.4 & 20.67 & $\star<0.05$ \\
\hline Unemployed & 9.0 & 14.33 & $*<0.05$ \\
\hline Deceased & 13.14 & 13.67 & $>0.05$ \\
\hline \multicolumn{4}{|c|}{ * Statistically Significant mean score } \\
\hline \multicolumn{4}{|c|}{ Distribution of means of scores by mothers' occupation in both schools } \\
\hline Occupation & Means of Scores in Wesley & Means of Scores in Onitolo & Kruskal Wallis P Value \\
\hline Doctors, Scientists & 17.89 & 16.18 & $>0.05$ \\
\hline Small business owners, teachers & 12.27 & 17.17 & $>0.05$ \\
\hline Clergy, Pastors & 14.91 & 9.15 & $>0.05$ \\
\hline Factory workers, agricultural workers & 9.17 & 17.8 & $>0.05$ \\
\hline Domestic servants, casual employees & 17.0 & 23.0 & $>0.05$ \\
\hline Unemployed & 15.10 & 12.50 & $>0.05$ \\
\hline Deceased & 13.0 & 4.67 & $>0.05$ \\
\hline
\end{tabular}

In Wesley School, a 31 year old man was found in primary six but was not included in the study. The mean score in primary four respondents from Onitolo School were 5.95 points higher than the mean score for primary four respondents from Wesley School. This was statistically significant for Kruskal Wallis $P$ value $(P<0.05)$. The highest mean scores were from the primary six classes in the two schools. In both schools, males scored higher than females.

The performance of all the respondents was statistically significant to their class and sex $(P<0.05)$. Students in the higher classes performed better than students in the lower classes and males had higher scores. In both schools, the highest scores were from primary six respondents. The overall highest score was from a primary six male from Wesley School whose mother is a teacher and whose father owns a small business.

Respondents that were older in both schools had higher scores. Respondents who had skilled fathers had the highest mean score in Onitolo School. In Wesley School, respondents of skilled mothers had the highest mean score. Respondents that were hearing-impaired from their first year of life scored higher than those who had become hearing-impaired after their first year of life although this was not statistically significant $(P>$ 0.05). A simple linear regression showed that the age the child became hearing-impaired was not a determinant of score $(P>0.05)$. Majority of the respondents $201(66.6 \%)$ had a score in the 1129 category. The means of scores in both schools were only statistically significant for respondents from primary four $(P<0.05)$.

A bivariate analysis of selected variables showed that age and sex were determinants of scores in Wesley School and class was a determinant of score in Onitolo School. When both schools were combined, class was the only determinant of score. 


\section{Discussion}

A greater proportion of the respondents were Yorubas. This was not surprising as Lagos State is mostly occupied by the Yorubas. In Wesley School, the respondents were much older (11-15 years old) than the pupils from Onitolo School (6-10 years old). This is because parents of the hearing-impaired enrol their children in school at a later age than parents of children in the main stream school. As there is no educational facility for nursery education for the hearing-impaired, a lot of the hearing-impaired children may spend more than one year in primary one which is their first level of formal education.

The greatest numbers of respondents in Wesley School were from primaries one and six. There were large numbers of pupils in primary one because the pupils were just starting school and it thinned out and increased again towards primary six. Sometimes, the pupils get frustrated and drop out of school and after some years go back to school again. The school does not have boarding facilities and Wesley School is the only government owned school for the hearing-impaired in Lagos state. Some parents are unable to take their children because of the long distance from their home. Further, some parents are not aware of the school and they keep the child at home. When they decide to bring the child to school, the child may be exceptionally old as was the case of a 31 year old man in Primary one. This 31 year old pupil was not included in the study. In a study conducted on hearing-impaired pupils from two schools providing primary education in rural, south-eastern Nigeria, the oldest respondents were 31-35 years old and more respondents in that study were aged between 26 and 30 years old [23]. Majority of the respondents 201 (66.6\%) had a score in the 11-29 category on the non-verbal standard test. Equal percentages of respondents; (65\%) in each school had a Raven's score in the 11-29 category. Those in the higher classes performed better than those in the lower classes.
Three-quarters 76 (74.5\%) of the pupils were hearing-impaired by their first birthday. The parents reported that their child had had a fever, measles or jaundice at birth before $\mathrm{s} /$ he was noticed to be deaf. Pre-screening for sensorineural deafness would prevent delays in diagnosis and promote early interventions.

An 11 year old child in primary two had the highest score in his class. The child was from Wesley school. The mean score for his class was 16.20 but he scored 35. This child became hearing-impaired at the age of 9 years old. It is probable that the nine years of verbal instruction he had before he became hearing-impaired contributed to his performance.

In a study on the prior knowledge of hearingimpaired adolescents and their reading comprehension, adolescents that had a prior knowledge of the concepts scored better than those that had shallow concepts of the text [24]. Studies have also shown that children that are hearing-impaired have a higher level of visuospatial ability when compared to their non-hearing-impaired counterparts [7, 9].

A study of the cognitive processes used in solving the Raven's Progressive Matrices showed that responses were dependent on analytic intelligence [25]. Analytic intelligence does not depend on declarative knowledge but uses new information. Therefore, the child that becomes hearing-impaired at a later age may not be using prior knowledge but analytic knowledge. In addition, according to the study, the responses to the Raven's Progressive Matrices depend on each individual's visual spatial abilities [25].

A separate study on the profile analysis of hearing-impaired children using the universal non-verbal intelligence tests showed that there was no difference between the performance of children that were hearing-impaired and children that were not hearing-impaired [8]. This study has also shown that there was no difference in the performance of the hearing-impaired and the non-hearing-impaired. 
The males in both schools scored higher than the females in both schools. The results of this study agreed with a meta-analysis conducted on the gender differences in the scores from Raven's Standard Progressive Matrices [26]. In the meta-analytic study examining 2735 adolescents aged between 12 and 18 years old from Estonia, girls performed better than boys at the age of 12 and by the age of 14 , gender differences were not observed in their performance but at the age of 17, boys performed better [26]. The students in the meta-analytic study were not hearing-impaired. Further, it concluded that certain test items on Raven's Standard Progressive Matrices could only be solved by visual spatial reasoning and that a few items involving additions could only be solved by verbal, analytical reasoning. It further concluded that Gestalt continuation was also needed in solving some of the matrices [26].

Studies on the cognitive function of adults have showed that the educational level of parents is a predictive factor of educational success in later years [27]. A study conducted in Brazil showed that a low maternal education was associated with lower test scores on all the cognitive tests carried out on 12,977 adult participants aged between 35 and 64 years [27]. In New York, a study that followed participants for 40 years showed that the respondents' parents' educational level while they were at middle school, positively correlated with their own educational and occupational achievements in their adult life [28].

In this study, the children of skilled parents scored highest on the standard non-verbal tests. This agrees with other studies that have pointed out that parental occupation was related to the intelligence level of the child and children of skilled professions tend to score higher than children of unskilled parents [29].

The respondents that were hearing-impaired by their first year of life scored higher than those who became hearing-impaired after their first year of life $(P>0.05)$. It could be that parents of children who became hearing-impaired by their first year of life sought help faster and enrolled their children in school earlier than parents of children who became hearing-impaired after the first year of life [8]. A study conducted in Ibadan, Nigeria showed that the mean age at diagnosis of sensorineural hearing loss was 5.8 years [10]. Therefore, it could also be that some respondents became hearing-impaired before their first year of life and the diagnosis was not made until more years had passed.

This delay in diagnosis would have made some parents seek help much later than those diagnosed before their first year of life. Infant screening for hearing loss is not routinely done in Nigerian hospitals but when 100 Nigerian mothers were asked if they would like their babies to be screened for hearing loss, $92 \%$ wanted their babies to be screened [30].

The simple linear regression showed that the age at which a child became hearing-impaired was not a determinant of score $(P>0.05)$. The Raven's Standard Progressive Matrices depends on analytical knowledge and prior knowledge may not be necessary in solving the matrices [25]. The variables of class, sex, age and parents' occupations were adjusted for matching by multiple regression analysis [31]. In the bivariate analysis, age and class were predictors of performance $(P<0.05)$. However, when multiple regression analysis was conducted on selected variables including those that were not statistically significant in the bivariate analysis, age, sex and class were predictors of performance $(P<$ 0. 05).

When the hearing-impaired are given equal opportunities in education, they would be able to live independent lives, contribute to the development of the country and would also reduce the economic and social burden on their parents and on the society.

\section{Recommendations}

1 Equal opportunities especially in the area of education should be given to hearing-impaired 
children. More educational facilities for primary, secondary and post-secondary education should be provided to accommodate the hearing-impaired.

2. Educational facilities for the hearing-impaired children that are less than six years old should be established so that they can be well-prepared by the time they start school in primary one. It would also prevent students as old as 31 years being in primary one because they would have enrolled at an earlier age.

3. Wesley School is the only government operated school for the hearing-impaired in Lagos State. Transportation to these schools should be provided as many parents that knew about the school faced transportation challenges.

4. There should be health education to parents of children with hearing impairment informing them of the resources present in Wesley School. Several of the pupils started school late because they were not aware of the school and when they became aware, the school was too far from their homes and the children became one of the oldest in the class.

5. Students that are hearing-impaired should be discouraged from dropping out as a lot of the children drop out of school. The government might provide an incentive for those who complete their primary school education.

6. Schools like Wesley School for the hearingimpaired should be replicated across the state to increase geographic and economic access.

7. Pre-screening of infants should be incorporated into well baby clinics to detect sensorineural hearing loss and to promote early intervention. More than three -quarters of the respondents from Wesley school became hearing-impaired before the age of one year.

\section{Conclusion}

In comparing the cognitive function of the hearing impaired and the non-hearing impaired pupils using the standard non-verbal tests like the Raven's Standard Progressive Matrices, there was no difference in their cognitive function $(P>0.05)$. The highest mean scores were from primary six pupils in the two primary schools. Using multiple regression analysis, age, sex and class were found to be determinants of performance $(P<0.05)$. In both schools, the mean scores for males were higher than the mean scores for females.

Using simple linear regression, it was found that the age a child became hearing-impaired was not a determinant of performance on the standard non-verbal tests even though children who became hearing-impaired by their first year of life had higher mean scores. Majority of the respondents $201(66.6 \%)$ had a score in the 11-29 category on the non-verbal standard test. The children of skilled parents scored highest on the standard non-verbal tests.

The hearing-impaired students were older at the entry age into primary school because there was no hearing impaired educational facility below the primary school age which means that by the time they start school, they would have missed the gains achieved by their non-hearing impaired peers. Children that are hearing-impaired should be given equal opportunities especially in education. 


\section{Acknowledgments}

The author wishes to express her appreciation to the parents of the pupils, the pupils and the entire staff of Wesley School and Onitolo School. The author acknowledges Mr. A. O. A; the Principal and Mrs. M.I. O, the Vice-Principal for the oral history of Wesley School. She acknowledges Mr. J.A. A, the Principal, for the oral history of Onitolo Primary School.

The author thanks the management of Lagos University Teaching Hospital, Nigeria my employer at the time of the study. She also thanks the Sta$\mathrm{ff}$ of the Department of Community Health, Lagos University Teaching Hospital.

The author would also like to acknowledge Virginia Polytechnic Institute and State University's Open Access Subvention Fund (OASF).

\section{Author Contributions}

TTO selected the study design, assisted in data collection and analysis. TTO wrote the entire manuscript.

\section{Conflicts of Interest}

None

\section{References}

1. UNICEF. World Declaration on the Survival, Protection and Development of Children [cited 2015 February,10] Available from: http://www.unicef.org/wsc/declare.htm

2. Universal Basic Education Commission (UBEC): About UBEC:[cited 2015 February,10] Available from: http://ubeconline. com/about_ubec.php

3. Omiegbe $O$. Superstitious beliefs associated with the handicapped in Africa. In A. O. Orubu (Ed.), African traditional religion (a book of selected readings). Benin City, Nigeria: Institute of Education University of Benin 2001: 62-72.

4. Ntukidem PJ, Ntukidem EP, Eyo EE. Resource Availability and Distribution in Public and Private Special Education Schools in Cross River State, Nigeria. International Education Studies. 2011; 4(3): 119-123.

5. Obiakor FE, Offor MT. Special Education Provision in Nigeria: Analyzing Contexts, Problems, and Prospects. International Journal of Special Education. 2011; 26(1): 25-32.

6. Njoku AC, Ihugba OA. Unemployment and Nigerian Economic Growth (1985-2009). Mediterranean Journal of Social Sciences. 2011; 2(6): 23-32.

7. Marschark M. Intellectual functioning of deaf adults and children: Answers and questions. Eur J Cogn Psychol, 2006; 18 (1), 70-89.

8. Vernon M. Fifty years of research on the intelligence of deaf and hard-of-hearing children: A review of literature and discussion of implications. J Deaf Stud Deaf Educ, 2005; 10 (3), 225-231.

9. Parasnis I, Samar VJ, Bettger JG, Sathe K. Does deafness lead to enhancement of visual spatial cognition in children? Negative evidence from deaf nonsigners. Journal of Deaf Studies and Deaf Education. 1996; 1(2): 145-152.

10. Lasisi O, Ayodele J, ljaduola G. Challenges in management of childhood sensorineural hearing loss in sub-Saharan Africa, Nigeria. International journal of pediatric otorhinolaryngology. 2006; 70(4): 625-629.

11. Raven JC. Standard Progressive Matrices Sets A, B, C, D and E. 1958. Lewis \& Co Ltd London.

12. Fukuda T. A survey of the intelligence and environment of school children. The American Journal of Psychology. 1925:124-139.

13. Naglieri JA, Ford DY. Addressing underrepresentation of gifted minority children using the Naglieri Nonverbal Ability Test (NNAT). Gifted Child Quarterly. 2003; 47(2): 155-160.

14. Ferguson KT, Cassells RC, MacAllister JW, Evans GW. The physical environment and child development: An international review. International Journal of Psychology. 2013;48(4):437468. 
15. Ghazi HF, Isa ZM, Aljunid S, Shah SA, Tamil AM, Abdalqader $M A$. The negative impact of living environment on intelligence quotient of primary school children in Baghdad City, Iraq: a cross-sectional study. BMC public health. 2012;12(1):562. [cited 2015 February 13] available from http://www.biomedcentral. com/content/pdf/1471-2458-12-562.pdf

16. World Health Organization (WHO) (1980). International Classification of Impairment, Disability \& Handicap (ICIDH). Geneva: World Health Organization. [cited 2015 February,10] Available from :http://whqlibdoc.who.int/ publications/1980/9241541261_eng.pdf

17.World Health Organization (WHO) Classifications:International Classification of Functioning, Disability and Health (ICF) 2001 [cited February 9, 2015] Available from: http://www.who.int/ classifications/icf/icf_more/en/

18. WHO ICD-10 International Statistical Classification of diseases and related health problems. Tenth Revison Volume 2. 2004. [cited February 9, 2015] Available from: http://www.who.int/ classifications/icd/ICD-10_2nd_ed_volume2.pdf?ua=1

19. Brewer RI. A note on the changing status of the Registrar General's classification of occupations. British Journal of Sociology. 1986: 131-140.

20. Mannetje AT, Kromhout $\mathrm{H}$. The use of occupation and industry classifications in general population studies. International Journal of Epidemiology. 2003; 32(3): 419-428. doi: 10.1093/ije/ dyg080

21. Liberatos $P$, Link BG, Kelsey JL. The measurement of social class in epidemiology. Epidemiologic reviews. 1988; 10(1): 87-121.

22. CDC. EPI INFO 7[cited 2015 February 13] available from: http:// wwwn.cdc.gov/epiinfo/

23. Groce N, Yousafzai A, Van der Maas F. HIV/AIDS and disability: Differences in HIVIAIDS knowledge between deaf and hearing people in Nigeria. Disability \& Rehabilitation. 2007;29(5):367371.

24. Jackson DW, Paul PV, Smith JC. Prior Knowledge and Reading Comprehension Ability of Deaf Adolescents. Journal of Deaf Studies and Deaf Education. 1997; 2(3): 172-184. doi: 10.2307/23802927

25. Carpenter PA, Just MA, Shell P. What one intelligence test measures: a theoretical account of the processing in the Raven Progressive Matrices Test. Psychological review. 1990; 97(3): 404-431.
26. Lynn R, Irwing P. Sex differences on the progressive matrices: A meta-analysis. Intelligence, 2004; 32 (4) 411-424.

27.Araújo LF, Giatti L, Chor D, Passos VMA, Barreto SM. Maternal education, anthropometric markers of malnutrition and cognitive function (ELSA-Brasil).BMC Public Health 2014;14:673. doi:10.1186/1471-2458-14-673.

28. Dubow EF, Boxer P, Huesmann, LR. Long-term effects of parents' education on children's educational and occupational success: Mediation by family interactions, child aggression, and teenage aspirations. Merrill-Palmer Q (Wayne State Univ. Press),2009; 55(3), 224-249. doi: 10.1353/mpq.0.0030.

29. Guilford JP. The nature of human intelligence. 1967. NY; McGraw-Hill.

30. Olusanya B, Luxon L, Wirz S. Maternal views on infant hearing loss in a developing country. International journal of pediatric otorhinolaryngology. 2006; 70(4): 619-623.

31. Bland JM, Altman DG. Statistics notes: Matching. BMJ. 1994; 309(6962): 1128.

\section{Comment on this article:}

\section{(f) $[$ in $8+\mathbf{S} P$}

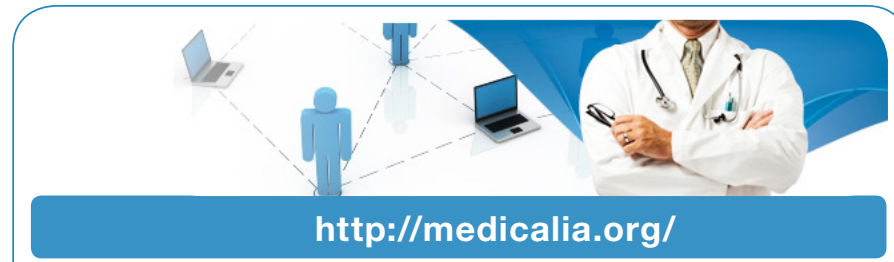

Where Doctors exchange clinical experiences, review their cases and share clinical knowledge. You can also access lots of medical publications for free. Join Now!

\section{Publish with iMedPub}

\section{http://www.imed.pub}

International Archives of Medicine is an open access journal publishing articles encompassing all aspects of medical science and clinical practice. IAM is considered a megajournal with independent sections on all areas of medicine. IAM is a really international journal with authors and board members from all around the world. The journal is widely indexed and classified Q1 in category Medicine. 